\title{
Efficiency Analysis of Equity Incentive in Private Listed Companies-By Taking the Example of By-Health
}

\author{
Junda Yang ${ }^{1}$, Yun Xia ${ }^{1}$, Liu Yang ${ }^{1}$, \& Zhongtao Zhang ${ }^{1}$ \\ ${ }^{1}$ Finance Department of International Business School, Jinan University, Zhuhai, China \\ Correspondence: Yun Xia, Finance Department of International Business School, Jinan University, Qianshan Road 206, \\ Zhuhai City, Guangdong Province, Post No.519070, China. Email: 13676097885@163.com
}

Received: October 5, 2018

Accepted: October 26, $2018 \quad$ Online Published: October 29, 2018

doi:10.11114/bms.v4i4.3725

URL: https://doi.org/10.11114/bms.v4i4.3725

\begin{abstract}
At present, more and more private listed companies in our country realize the importance of corporate governance structure and equity structure, and also start to adopt a variety of equity incentive models to stimulate the business operators. How to evaluate the effect of private listed company's equity incentive measures? By taking the example of By-Health, this paper analyzes the effect of implementing equity incentive from financial performance, manager's behavior and market performance from three aspects: financial performance, manager's behavior and market performance, and puts forward relevant suggestions. With a view to providing useful reference and reference for improving the management of private enterprises and implementing equity incentives smoothly.
\end{abstract}

Keywords: equity incentive, stock option, By-Health

\section{Introducation}

\subsection{Meaning of Equity Incentive}

At present, the governance structure and ownership structure of listed companies are more and more highly valued by managers. The management technology is increasingly complex and diverse, and the listed companies also study and create a variety of ways and means to effectively motivate managers. Equity incentive is one of the most widely used. The incentive of equity is to make the operator of the company, that is, the top management, owns the company's stock (the company's ownership) in a variety of ways, making it one of the shareholders of the company. In this way, the interests of the operator and the owner of the company become consistent, becoming the relevant interest community, and the high-level managers will stand at the angle of the shareholders to operate the company, participate in the decision-making and profit distribution of the company. Shareholders can also get excess returns from corporate growth so as to achieve mutual win-win.

\subsection{Mode of Equity Incentive}

At present, there are various incentive modes used by the private listed companies in our country, including stock option, stock increment right, restrictive stock, virtual equity, deferred payment, management/ employee acquisition, etc. However, the equity incentive scheme adopted by listed companies mainly concentrates on the three modes of stock option, restrictive stock and stock value added, and the mixed modes.

\subsubsection{Stock options}

Refer to the power that a listed company grants incentive objects to purchase a certain quantity of shares of the Company at predetermined prices and conditions within a certain period of time. The predetermined price is referred to as the price of the line of sale. If the right price is higher than the company's stock price at the time of sale, the holder can give up the price; On the contrary, if it is lower than the stock price of the company, it is possible to buy the shares at a lower price, and the difference between the market value and the sales price is the income obtained by the holder. For the enterprise owner, the function of the stock option is to bond the enterprise manager with the benefit of the owner of the enterprise without paying any cash cost, so as to motivate the enterprise manager to stably provide the enterprise value maximization service for the long term. 


\subsubsection{Value-Added Rights of Stocks}

It refers to a right that a listed company grants incentive objects, that is, if the stock price of the company rises, the incentive object can get a corresponding quantity of stock price appreciation gains through the stock price. The incentive object does not need to pay cash for the depositor, and the company shares the cash or the equivalent of the company after the payment. The incentive object of the value-added right of the stock does not actually own shares, nor does it have the right to share dividends, the right to vote, and the distribution of shares.

\subsubsection{Restricted Stock}

Refer to a certain amount of shares to be granted by a listed company in advance. If the conditions such as the working life, performance or stock market value of the incentive target meet the prior agreement, the restricted stock can be sold and the income can be obtained accordingly. Each listed company can design and sell conditions according to the actual situation of itself, and has certain flexibility.

\section{Theoretical Foundation and Literature Review}

How to evaluate the effect of equity incentive scheme is that the greater the effect of equity incentive to improve the value of an enterprise, the better the implementation effect. Hua Banghua (2002) holds that the higher the contribution of the implementation of equity incentive to the improvement of enterprise value, the higher it is. Therefore, the validity of equity incentive is that whether the equity incentive can actively promote the value of the enterprise and the interest of the owner of the company in a special environment can make the interests of the enterprise manager and the owner the same, thus exerting the stimulating effect on the incentive target, arousing the enthusiasm of his work and weaken the existing contradiction between the manager and the owner. The validity of equity incentive can be evaluated in three aspects: corporate finance performance, management behavior and market performance.

\subsection{Financial Performance}

The effect of equity incentive is mainly expressed as to whether there is a significant increase in the effect of equity incentive before and after the implementation. Most documents use accounting financial indicators to evaluate the financial performance of the company's equity incentive, and measure it from aspects such as profitability index, management ability index, debt-paying ability index, and long-term index. Wang Qiuxia and Chen Xiaoyi (2009) balances the indicators as profitability (net assets return rate, total assets yield), management capacity index (total assets turnover, inventory turnover), debt-paying ability index (asset-liability ratio, interest multiple), growth performance indicators (main business income growth rate, net assets growth rate) to measure the operating performance of 19 listed companies in 2006-2007. Zhao Huawei (2016) uses the performance indicators such as the Tobins'Q value, the total assets return rate and the return rate of the net assets to comprehensively inspect the accounting performance of the company implementing the executive equity incentive in the investigation period. Chen Yong, Liao Guanmin and Wang Ting (2005) adopted three-year average net income change as an index to measure the change of financial performance after the implementation of equity incentive. Li Chunling and Ren Lili (2013) not only analyzed the change of indicators, but also took the growth rate of main business revenue as an indicator to evaluate the performance. In addition, in the financial performance analysis, it is also possible to examine the gold content of the revenue profits from the sales collection rate and the net profit. In addition to considering the use of current ratios and quick-moving ratios, debt-servicing capacity needs to be combined with the company's development phase, so that further analysis of the company's financial position can be considered in view of increased interest guarantees. But it is not enough to consider accounting indexes to measure the effect of equity incentive, but also investigate the behavior of managers.

\subsection{Management Behavior}

Management has been able to share the remaining benefits of the company through equity incentives, and the remaining benefits of the company's performance growth will enable them to stay active for long periods of time. In order to gain equity incentives and share more benefits, managers will redouble their efforts and attach importance to decision-making. Management may increase the number of meetings, strengthen the company's internal controls to reduce expenses, including sales expenses, administrative expenses, etc. This paper compares the management cost and its net profit, as indicated by Wang Jinxiao (2012) in the performance of the equity incentive in the financial statements. The effective control of managers contributes to the improvement of performance, and performance promotion is one of the criteria to judge whether equity incentives are effective. Through the change of the management cost and the sales expense account for the operating income ratio, it can be seen whether the behavior of the manager before and after the implementation of the equity incentive effectively controls the cost, so that the effect of the equity incentive can be evaluated. But it is far from enough to look at executives from the data of the financial statements. Johnson (1999) made a sharp criticism of so many companies adopting absolute value index for performance appraisal. In his opinion, such a performance appraisal system has led to a bull run, and the performance of many companies, though less than the 
average market average, can still get high returns on options. The researchers of Berrand and Mulainathan (2001) also supported the idea that their research found that CEO pay levels are easily influenced by their luck, not their ability, and when the performance of the entire market and business sector is outstanding, CEO pay is also high. In addition, Healy (1985), Dechow and Sloan (1991) pointed out that using only accounting gains as an index of assessment could not only be manipulated by executives, but could lead executives to abandon projects that cut short-term corporate profits but long-term corporate profits, such as reducing research and development spending. Pan Ying and Liu Guangsheng (2009) studied the issue of equity incentive effect by taking stock-stock-driven listed companies as samples in 2004-2007. The research found that the stronger the balance force of medium and small shareholders to shareholders, the more obvious the effect of equity incentive implementation. Xia Yun (2014) investigated the effect of the Company's executive power on R \& D investment by using the power to influence the company's executive power from 2002 to 2009. The research found that the larger the executive power, the smaller the company's investment. Therefore, from the perspective of the long-term development of the enterprise, it is an important aspect to evaluate the implementation effect of the equity incentive of listed companies and the behavior of managers.

\subsection{Market Performance}

According to the effective market theory, the stock price reflects the important incentive system of the company, which significantly affects the investors' expectation of the future. From the past literature research, most scholars mainly employed the excess cumulative yield to describe the market reaction. For example, Huang Hong, Zhang Ming and Liu Lin (2014) used the event research method to measure the change of accumulated excess yield to measure the market reaction before and after the equity incentive scheme. But different scholars use different lengths in the selection of the window period. Zhang Ying and Zheng Xueqing (2008) set the window period to 21 trading days after the event. Qing Xue (2016) set the window opening time to 10 days. Lv Changjiang et al. (2009), on the basis of the announcement date of the draft equity incentive issued by the resolution of the board of directors, shall be used as the window period for one to three days before and after the benchmark date. A shorter event window could eliminate the effects of other events on the stock price, but not comprehensive enough. A long window period increases the risk of noise due to the common action of other events.

Therefore, it is important to select a suitable window period. In the past, the analysis of market reaction was too simple, it can try to analyze the extent of institutional investors' intervention and the market response after equity incentive. Institutional investors have a relatively objective analysis of the sustainability of the company's performance and the improvement of corporate governance mechanisms. They tend not to miss the company with investment value.

Taking the stock ownership incentive scheme of the private listed company of Zhuhai City as an example, this paper analyzes the incentive measures of the equity incentive in the By-Health and analyzes the concrete effect of the implementation of the equity incentive scheme from three aspects: financial performance, manager behavior and market performance, to provide useful reference for improving management of private enterprises and implementing equity incentives smoothly.

\section{Analysis on the Equity Incentive Mechanism of By-Health}

\subsection{General Situation of By-Health Co., Ltd.}

Established in Oct. 1995 with a registered capital of RMB 1,470 million, By-Health Co., Ltd. introduced the dietary supplement into the non-direct marketing area of China in 2002, and quickly developed into the leading brand and benchmarking enterprise of Chinese dietary nutrition supplement. It is also the first AAA Chinese health-care enterprise in China's health-care industry. In Dec. 2010, the Company was officially listed. It is mainly engaged in R \& D, production and sales of dietary nutrition supplement. It is a leading enterprise in the non-direct sales field of Chinese dietary nutrition supplement industry. It is a high-tech enterprise in the field of biology and new medicine technology. It has a professional production base covering many dosage forms such as soft capsule, hard capsule, tablet, powder and so on. It has a huge sales network and chain network covering the non-direct sales field of the industry, and has a strong channel brand in the industry. It is one of the enterprises with less competition for foreign brands in our national brand.

The company began to implement the incentive program in 2013, and the first grant of the stock option was divided into three periods, and the annual appraisal year was from 2013 to 2015.The performance appraisal is based on the net profit of 2012, which is not less than $40 \%, 82 \%$ and $136 \%$ respectively from 2013 to 2015 ; The return rate of net assets in the corresponding year is not less than $16 \%, 18 \%$ and $20 \%$, respectively. However, after the issuance of the equity incentive scheme, except for the equity incentive payment in 2013 (the net profit of By-Health in 2013 is more than $40 \%$ in 2012 and the annual net assets return rate is not lower than 16\%), the equity incentive targets have not been met in 2014 and 2015. 


\subsection{Driver of Equity Incentive}

The motivation of the implementation of the equity incentive by By-Health Company mainly includes the following two aspects:

Firstly, equity incentive shows the company's confidence, which is conducive to the long-term development. The Company issued an equity incentive advertisement to grant 2.33 million shares of stock options to the incentive target, accounting for $23.2 \%$ of the total share capital of the Company at the time of signing the incentive scheme. The incentive targets are senior management personnel, core technology (business) personnel and sub-(son) company's main management personnel in the company, with a total of 135.This plan is mainly to motivate senior middle-ranking employees of the Company, which is conducive to the long-term development of the Company.

Secondly, it is committed to promoting brand effect and focusing on endogenous growth.2012 is a very strict year for industry regulation, and the whole industry of health care products was affected by "Capsule problem", but the company's net profit growth remains $40 \%$ to $60 \%$, continuing the momentum of good development in 2011.In 2012, the company is committed to the refinement of the terminal. Through the establishment of a nutrition institute, it cultivates nutritionist for terminal pharmacies. It established a major clients department, to provide a one-to-one guidance and promotion of key terminal customers and distributors and the like, to enhance the brand effect. From the view of the extension, the company established 9,000 new terminals in 2012, which is expected to reach 30,000 by the end of 2012 . There are still larger lifting space from the 6-7 million key terminals of OTC drugs. The future extension expansion will be robust.

The implementation of the incentive scheme of the stock option is to further improve the corporate governance structure, promote the establishment of a robust long-term incentive and restraint mechanism, encourage the initiative and creativity of the incentive object of the company, to enhance the corporate management team and business backbone to realize the responsibility and mission of the company's "healthy, sustained, fast" development, and to ensure the long-term development goal of the company.

\subsection{Analysis on the Key Points of the Equity Incentive Scheme of By-Health Co., Ltd}

In 2013, By-Health launched an equity incentive scheme for the first time, as shown in the following table:

Table 1. By-Health Company's Arrangement for the First Equity Incentive Scheme

\begin{tabular}{|c|c|c|c|c|}
\hline & \multirow{2}{*}{$\begin{array}{l}\text { Option shares } \\
\text { (Unit:10,000) }\end{array}$} & \multirow{2}{*}{$\begin{array}{l}\text { Exercise } \\
\text { price }\end{array}$} & \multicolumn{2}{|c|}{ Exercise conditions } \\
\hline & & & $\begin{array}{l}\text { Net profit } \\
\text { growth rate }\end{array}$ & $\mathrm{ROE}$ \\
\hline The first exercise period & 63.90 & 12.96 & $40 \%$ & $16 \%$ \\
\hline $\begin{array}{l}\text { The second exercise } \\
\text { period }\end{array}$ & 63.90 & 16.99 & $82 \%$ & $18 \%$ \\
\hline The third exercise period & 85.20 & 20.30 & $136 \%$ & 205 \\
\hline
\end{tabular}

Table 2. The arrangement of options and arrangement for the first time in By-Health Co., Ltd.

\begin{tabular}{lll}
\hline $\begin{array}{l}\text { First grant option } \\
\text { exercise period }\end{array}$ & \multicolumn{1}{c}{ Exercise time } & $\begin{array}{c}\text { Exercise } \\
\text { ratio }\end{array}$ \\
\hline $\begin{array}{l}\text { The first exercise } \\
\text { period }\end{array}$ & $\begin{array}{l}\text { From the first trading day 12 months after the date of } \\
\text { first authorization to the last trading day within 24 } \\
\text { months after the date of first authorization }\end{array}$ & $30 \%$ \\
\hline $\begin{array}{l}\text { The second exercise } \\
\text { period }\end{array}$ & $\begin{array}{l}\text { From the first trading day of the first authorization day } \\
24 \text { months later to the last trading day of the last } 36 \\
\text { months from the first authorization day }\end{array}$ & $30 \%$ \\
\hline $\begin{array}{l}\text { The third } \\
\text { period }\end{array}$ & $\begin{array}{l}\text { From the first trading day of 36 months from the first } \\
\text { authorization day to the last trading day of 48 months } \\
\text { from the first authorization day }\end{array}$ & $40 \%$ \\
\hline
\end{tabular}


Table 3. Right-exercising Arrangement of Reserve Options of By-Health Co., Ltd.

\begin{tabular}{|c|c|c|}
\hline $\begin{array}{l}\text { Reserved } \\
\text { exercise period }\end{array}$ & Exercise time & Exercise ratio \\
\hline The first exercise period & $\begin{array}{l}\text { The first trading day after } 12 \text { months from } \\
\text { the pre-authorization date to the last } \\
\text { trading day within } 24 \text { months from the } \\
\text { pre-authorization date }\end{array}$ & $50 \%$ \\
\hline $\begin{array}{l}\text { The second exercise } \\
\text { period }\end{array}$ & $\begin{array}{l}\text { The first trading day after } 24 \text { months from } \\
\text { the pre-authorization date to the last } \\
\text { trading day of } 36 \text { months from the } \\
\text { pre-authorization date }\end{array}$ & $50 \%$ \\
\hline
\end{tabular}

\subsubsection{Rights-Exercise Conditions}

The achievement goal is an important part of the equity incentive scheme. Only the enterprises that can meet the planned target can meet the pre-established goals can they exercise the rights. Generally, the market indicators such as ROE, net profit growth rate and other market indicators can be used. The purpose of setting incentive conditions is to make the granting of options closely linked to the performance appraisal results of incentive targets. The incentive conditions are set up by the company themselves, and the incentive conditions of the incentive programs cannot set up a substantive door for the incentive targets, which leads to the failure of the whole equity incentive scheme to achieve the real incentive role. From Table 1, you can see that the performance targets set by By-Health are net asset yields and net profit growth rates.

Taking the ROE of the first-phase incentive scheme as an example, we can see from Table 5 that, in 2012, the net assets return rate of By-Health Company is only $15.18 \%$, and the annual report of 2013 shows that the return rate of net assets is $20.29 \%$, while the return rate of net assets is only $16 \%$. The company raised the benchmark index by 0.82 percentage points on the basis of 2012 and continued to increase over the next two years. ROE's performance rose to $20 \%$ in 2015 (benchmark in 2012), which has a great appeal to investors.

According to Table 4, the net profit growth rate index of the equity incentive scheme of the company is analyzed. Based on the net profit 280 million of 2012, the first phase of equity incentive scheme requires the net profit of 2013 to reach the 392 million, and the performance index of net profit growth rate based on $82 \%$ of net profit in 2014 is RMB 509.6 million and it realized RMB 660.8 million in 2015. This incentive condition is more incentive to perform under the trend of performance growth.

Table 4. Performance appraisal conditions for the equity incentive scheme of By-Health Co., Ltd.

\begin{tabular}{ll}
\hline Exercise period & Performance assessment conditions \\
\hline $\begin{array}{l}\text { First grant option first exercise } \\
\text { period }\end{array}$ & $\begin{array}{l}\text { Based on the net profit in 2012, the net profit in 2013 increased by no less } \\
\text { than } 40 \% \text { compared with that in 2012, and the return on net assets in that } \\
\text { year was no less than } 16 \%\end{array}$ \\
\hline $\begin{array}{l}\text { First grant option second exercise } \\
\text { period / Reserved option first } \\
\text { exercise period }\end{array}$ & $\begin{array}{l}\text { Based on } 2012 \text { net profit, 2014 net profit increased by no less than } 82 \% \\
\text { compared with 2012, and the return rate of net asset was no less than } 18 \%\end{array}$ \\
\hline $\begin{array}{l}\text { First grant option second exercise } \\
\text { period / Reserved option second } \\
\text { exercise period }\end{array}$ & $\begin{array}{l}\text { Based on the net profit in 2012, the net profit in } 2015 \text { increased by no less } \\
\text { than 136\% compared with that in 2012, and the return rate of net assets in } \\
\text { that year was no less than } 20 \%\end{array}$ \\
\hline
\end{tabular}

\subsubsection{Rights Exercise Validity Period}

The first-phase equity incentive scheme of By-Health Company was started in 2013, with a one-year waiting period before each equity incentive scheme, so that the duration of the continuous cross-ownership incentive scheme can only be completed by 2016, and the equity incentive time is 4 years. Short-term rights exercise will allow executives to have incentive to gain high returns in the short term through stock-price manipulation. On the contrary, the long-term incentive validity period is likely to give play to the effect of equity incentive. At present, more than $75 \%$ of companies in our country set the incentive validity period to 5 years and below, which indicates that the threshold value of the incentive validity period set by the company is relatively low and presents a new "sheep's effect". Meanwhile, nearly $25 \%$ of the company's incentive validity period is less than 5 years, and the motivation of its executive well-being is more obvious. 


\subsubsection{Incentive Object}

The first-phase equity incentive scheme is granted to 2.13 million, accounting for $90.1 \%$ of the total number of equity grants in the plan, accounting for $90.1 \%$ of the total share capital of the Company at the time of signing the incentive plan; 200000 are reserved, accounting for $8.58 \%$ of the total number of stock options granted for this plan, accounting for $0.09 \%$ of the total share capital of the Company at the time of signing this incentive plan. The incentive targets granted for the first time in the Project are senior management personnel in the Company, core technology of the Company and key personnel of the business affairs, and sub-(son) main management personnel of the Company. By-Health's equity incentive involves a range of key posts from the top to the bottom of the company's control layer.

\subsection{Effectiveness Analysis of Equity Incentive}

\subsubsection{Financial Performance Evaluation}

The first phase of the stock ownership incentive scheme of By-Health was achieved in 2013, and no requirement was reached in 2014 and 2015. In order to further illustrate the effectiveness of equity incentive, the financial performance of the Company is analyzed further.

In this paper, the financial situation after the implementation of the equity incentive scheme by By-Health Company is mainly analyzed from several aspects of short-term debt-paying ability, long-term debt-paying ability, operation ability and profitability. The main financial indicators of By-Health Company for 2012-2015 are as follows:

Table 5. Main financial indicators of By-Health Co., Ltd for 2012-2015

\begin{tabular}{lllll}
\hline & 2012 & 2013 & 2014 & 2015 \\
\hline Working capital & 14.51 & 16.46 & 16.67 & 28.05 \\
\hline Current ratio & 9.54 & 8.69 & 7.86 & 9.37 \\
\hline Quick ratio & 8.30 & 7.60 & 6.92 & 8.45 \\
\hline Cash ratio & 7.40 & 7.15 & 6.34 & 4.30 \\
\hline Cash flow ratio & 0.66 & 2.93 & 2.31 & 1.90 \\
\hline Asset-liability ratio & $8.44 \%$ & $9.07 \%$ & $9.37 \%$ & $7.17 \%$ \\
\hline Equity ratio & 0.09 & 0.10 & 0.10 & 0.08 \\
\hline Equity multiplier & 1.09 & 1.10 & 1.10 & 1.08 \\
\hline Debt-to-long capital ratio & $0.46 \%$ & $0.37 \%$ & $0.41 \%$ & $0.37 \%$ \\
\hline Times interest earned & -8.30 & -13.64 & -12.51 & -13.44 \\
\hline Cash flow interest coverage multiple & -3.12 & -18.23 & -12.79 & -12.39 \\
\hline $\begin{array}{l}\text { Ratio of net cash flow from } \\
\text { operating activities to total of }\end{array}$ & $62.35 \%$ & $281.17 \%$ & $221.74 \%$ & $180.40 \%$ \\
liabilities & & & & \\
\hline Receivables turnover ratio & 36.11 & 38.49 & 40.75 & 47.64 \\
\hline Inventory turnover ratio & 6.60 & 6.67 & 7.33 & 8.44 \\
\hline Current assets turnover & 0.66 & 0.85 & 0.90 & 0.90 \\
\hline Working capital turnover rate & 0.72 & 0.96 & 1.03 & 1.03 \\
\hline Non-current assets turnover & 2.85 & 2.74 & 2.45 & 1.77 \\
\hline Total assets turnover & 0.54 & 0.65 & 0.66 & 0.59 \\
\hline Operating net profit margin & $26.17 \%$ & $28.51 \%$ & $29.59 \%$ & $27.31 \%$ \\
\hline Total net asset interest rate & $14.04 \%$ & $18.51 \%$ & $19.50 \%$ & $16.29 \%$ \\
\hline Net interest rate & $15.18 \%$ & $20.29 \%$ & $21.50 \%$ & $17.71 \%$ \\
\hline $\begin{array}{l}\text { Ratio of cash received from goods and } \\
\text { services to sales revenue }\end{array}$ & 1.07 & 1.15 & 1.11 & 1.13 \\
\hline $\begin{array}{l}\text { Net cash flow from } \\
\text { operating activities } \\
\text { (Unit:100,000,000) }\end{array}$ & 1.11 & 6.27 & 5.61 & 6.35 \\
\hline $\begin{array}{l}\text { Ratio of net operating cash } \\
\text { flow to net profit }\end{array}$ & $39.64 \%$ & $148.58 \%$ & $111.53 \%$ & $102.42 \%$ \\
\hline
\end{tabular}




\subsubsection{Analysis of Income and Profit Quality}

The quality of revenue and profits mainly depends on both the growth and the cash content.

The following figure depicts revenue and earnings growth for 2011-2015. It can be seen that the growth in operating revenues is slightly slow after the implementation of the equity incentive scheme in 2013, and the net profit continues to grow. The net profit rose from 280 million in 2012 to 422 million in 2014, and net profits in 2015 reached 2.2 times in 2012.

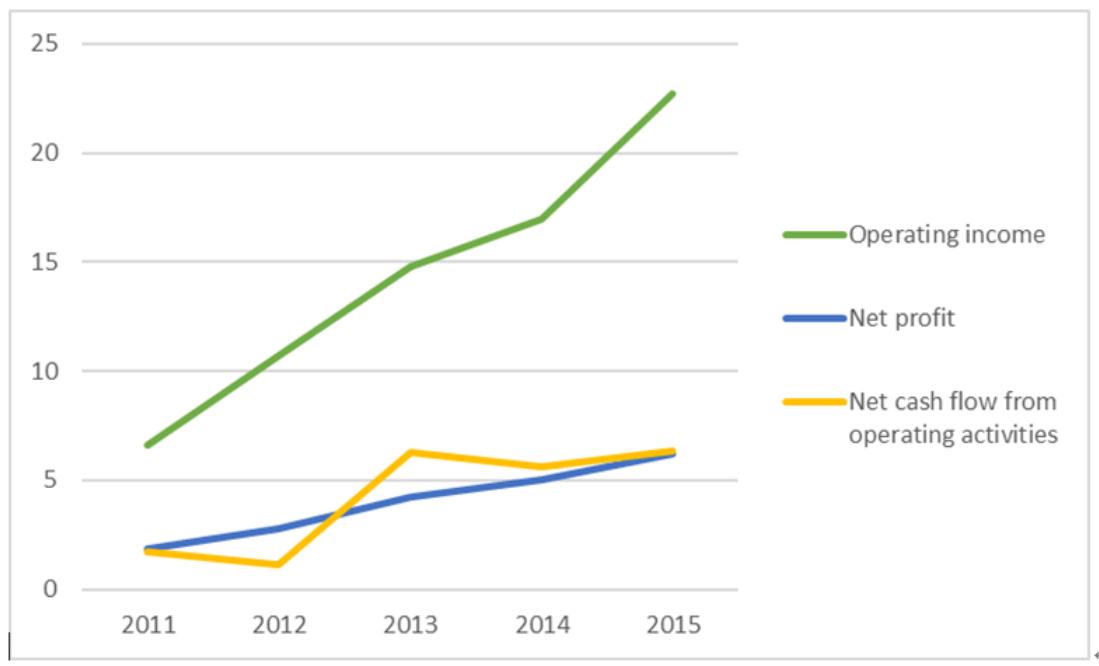

Figure 1. Variation trend chart of income and profit index of By-Health Company (Unit:100,000,000 RMB).

The gold content of the company's revenue is reflected by sales collection rate, which refers to the ratio of the cash received to the sales commodity to the operating revenue. It is generally considered that the ratio is more than 1 , and the gold content of the income is higher. From the data obtained in the company's annual report, the sales collection rate is more than $100 \%$, which indicates that the cash content of the company is very high. Since the cash items received by the sales commodity are recorded according to the collection and payment, the management's manipulation of income can be eliminated to some extent.

The cash content of profit can be reflected by the net profit rate, i.e. the ratio of net cash flow to net profit. Generally speaking, if the net cash flow is positive and the net profit index is close, the profit cash content of the company is higher. The cash net flow rate of the operation activities of By-Health company is continuously increasing, and the net profit rate is around $100 \%$ in 2013 , which shows good profit quality.

\subsubsection{Analysis of Profitability}

The core profitability of the Company is mainly measured by the rate of return of the net assets. As can be seen from the following table, in 2014, the return on net assets of the enterprise presents an upward trend from $15.18 \%$ in 2012 to $20.29 \%$ in 2013. At the same time, the net assets of the company rise from 1.93 billion yuan to 2.23 billion, and the company realizes higher return rate of net assets at the same time of scale growth, but cannot explain the fruitful work of the company's management.

Table 6. Dupont Analysis Index of the Return on the Net Assets of By-Health

\begin{tabular}{lllll}
\hline & \multicolumn{1}{c}{2012} & \multicolumn{2}{c}{2013} & \multicolumn{2}{c}{2014} & 2015 \\
\hline Equity multiplier & 1.09 & 1.10 & 1.10 & 1.08 \\
\hline Total assets turnover & 0.54 & 0.65 & 0.66 & 0.59 \\
\hline Net profit margin on sales & $26.17 \%$ & $28.51 \%$ & $29.59 \%$ & $27.31 \%$ \\
\hline ROE & $15.18 \%$ & $20.29 \%$ & $21.50 \%$ & $17.71 \%$
\end{tabular}

In order to further analyze the change of net assets return rate of the company, the paper uses the DuPont analysis method to decompose the return rate of net assets into the product of net interest rate, total asset turnover and equity multiplier. As can be seen from the table, there is little change in the net interest rate of the company, which fully shows that the competitiveness of the company's products and the company's control of costs have no significant changes. The analysis of the above table also reveals that the company's equity multiplier is relatively stable, which indicates that the company's operating state is relatively stable, and the management of the company does not increase the use of debt financing in the financing structure of the enterprise, and the risk that the company needs to bear is not large. 


\subsubsection{Analysis of Financial Position}

By-Health's financial situation is very robust. The following three aspects are as follows: First, the company's shareholders' equity is strong, and from the 1.93 billion yuan of 2012 to the 4.55 billion of 2015 , good security is formed for the debt. The asset-liability ratio of the company is around $9 \%$, the enterprise's capital is abundant, the debt service is guaranteed, but also the company's asset utilization rate is not high. Secondly, the company maintains strong profitability, and the enterprise obtains profits sufficient to guarantee the payment of interest expenses. From the table, it can be seen that the company's interest guarantee multiple is negative and the absolute value is greater than 1, indicating that the interest income of the enterprise is greater than 1, that is, the expense does not exist. Without paying the interest expense of debt, the enterprise is sufficient to guarantee the payment of interest expenses. Thirdly, the cash content of the company's income and profits is high, the cash net flow of the operation activities continues to grow, and also constitutes a good repayment guarantee for interest expenses. Fourthly, the current ratio of the company is about 8.8 , the rate of quick move is about 7.8, indicating that the company's short-term debt-paying ability is strong, although the short-term debt-paying ability of the enterprise has sufficient security, due to the large amount of funds occupied, the turnover speed of current assets and quick-moving assets is slowed down. The fund cannot give full play to the effective use benefit, and then affect the long-term production and management effect of the enterprise.

\subsubsection{Analysis of Management Behavior}

On Jan. 18, 2013, By-Health issued the first equity incentive to the senior management, core technology (business) personnel and sub-company (total of 135) of the company to 2.33 million stock options, accounting for $19.6 \%$ of the total 219 million share of the total share capital of the company at that time. After the issuance of the equity incentive plan, the net profit increased by more than $40 \%$ in 2012 and not less than 16\% in the year of 2014 and 2015, except that in 2013, the net profit increased by more than $40 \%$ in 2012, and the return rate of the net assets in the current year is not less than 16\%, and the target is not achieved in 2014 and 2015. So it can be deemed that By-Health's equity incentive plan does not achieve its original goals.

Given that equity incentives, management interests and corporate performance will be closely linked. If equity incentives are effective and management's delegated agency issues will be effectively mitigated, management should respond and, on the one hand, try to improve the company's performance, increasing the company's revenues or net profits, on the other hand, will reduce the costs to achieve sustainable growth in the company.

This paper mainly uses the absolute numbers and relative numbers of sales expense, total cost and business income to analyze the behavior change of managers. Sales expenses refer to the expenses incurred by enterprises in the process of selling products, self-made semi-finished products and providing labor services, including packing expenses, transportation fees, advertising expenses, loading and unloading fees, insurance premiums, commission charges and exhibition fees borne by the enterprises. Rental fees (excluding financing lease fees) and sales service fees etc. The total operating cost includes operating cost, business tax, bonus, sales expense, management expense, cash flow, impairment loss of assets and so on.

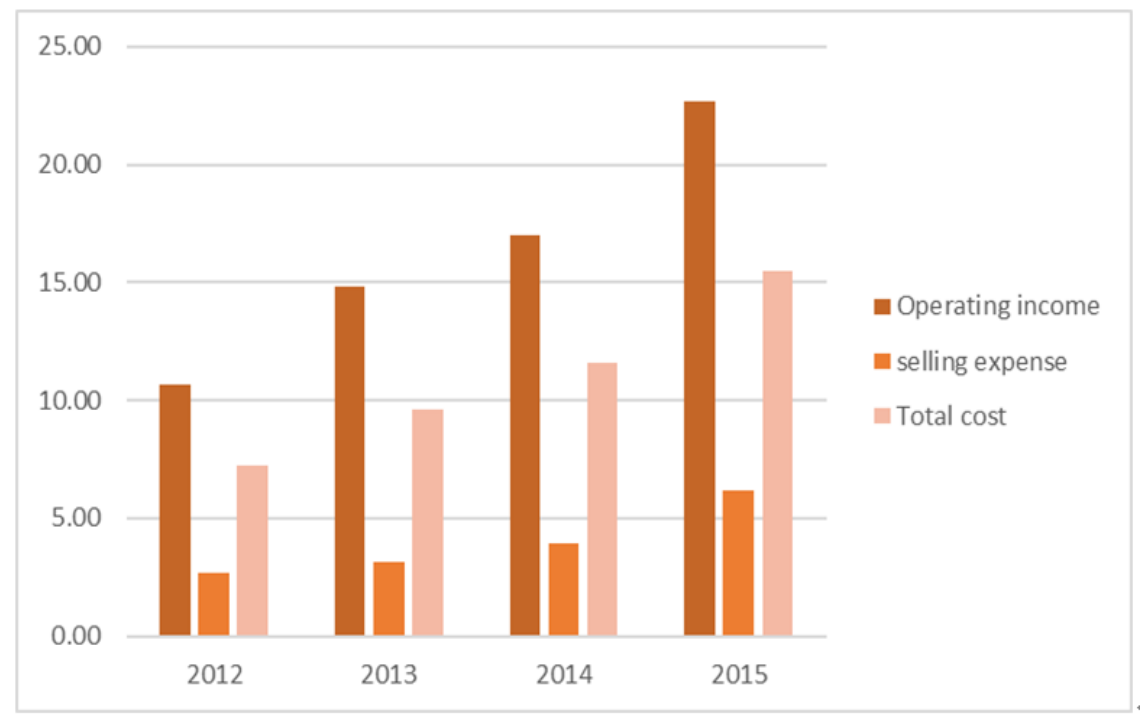

Figure 2. Operating income, sales expense and total cost of By-Health Co., Ltd (Unit:100,000,000 RMB)

From the above figure, we can see clearly that the company's sales expense, total operating cost and absolute value of 
operating income have always been increasing, indicating that the manager has the corresponding action, and the success of the company has gained a great increase in the company's performance. But let's look at the growth of relative numbers, and we use the following figure to further illustrate the company's growth.

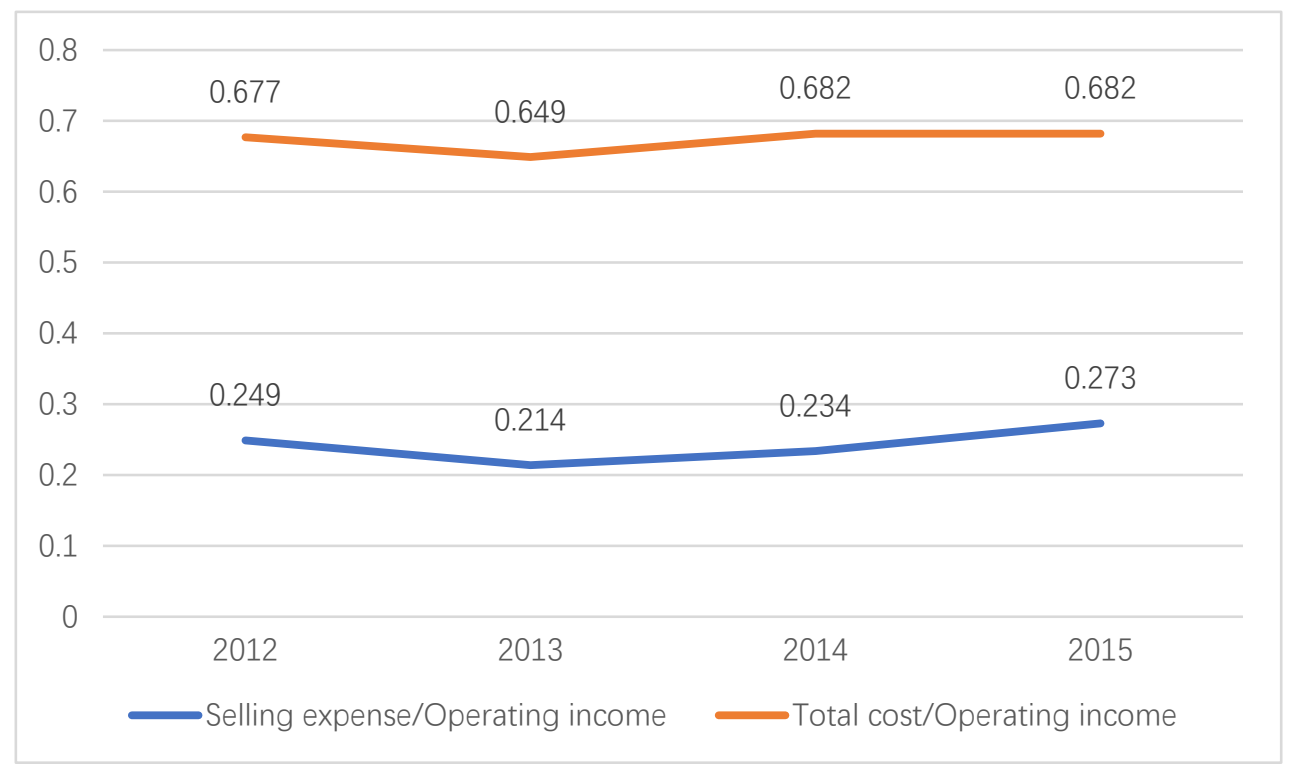

Figure 3. Sales expenses, total operating cost and business income relative number of By-Health Company

From the unit revenue sales cost curve, we can see that in the first year of the equity incentive scheme, that is, the unit revenue sales cost in 2013 is significantly reduced, down $16 \%$ on a year-on-year basis, but the revenue costs for the subsequent two years are increasing, The year-on-year rise of $9.5 \%$ in 2014 and $17.4 \%$ year-on-year in 2015.This shows that the managers of By-Health have succeeded through effective marketing method and cost control in the first year of the equity incentive scheme, and it also shows that equity incentive is temporary in the first year of the equity incentive scheme. However, since 2014, the cost of unit revenue sales in 2014 and 2015 is rapidly rising, reflecting the fact that managers have not been able to take effective ways to control unit revenue sales costs since 2014, even though the company's operating revenues have increased substantially, However, the cost and the cost can not be well controlled, so that the sales cost of the unit revenue is gradually increased, the growth of operating income is at the expense of the total operating cost, and the scale economy is not realized. This could partly explain why By-Health's equity incentive plan in 2013 was in effect in 2014, but the next two years failed to achieve the goal of failing to reach the target.

\subsubsection{Market Performance Evaluation}

\subsubsection{Analysis of Abnormal Return}

According to the effective market theory, the market will react to the company's governance in time, and the effectiveness of equity incentive scheme significantly affects the investor's expectation of the future. Based on the research from previous literature, the paper chooses the cumulative abnormal return to describe the market reaction. In this paper, we select $[-3,3],[-5,5],[-7,7]$ as the benchmark time point to calculate the on the basis of the announcement time (January 18, 2013) of the draft equity incentive draft published by the board of directors of By-Health Company, and select the shorter window period to eliminate the interference of other events.

Calculation method of cumulative abnormal return:

a. converting the company's stock price and the big city index into a daily yield (or rate of return):

Daily stock return $=($ day price-day before price $) /$ day before price

Daily Index Yield $=($ day index-day before index $) /$ day before index

b. Calculate the abnormal return (AR):

Abnormal Return $=$ Daily Stock Return-Daily Index Return

Cumulative yield, that is, the increase in stock prices in this section 
Table 7. Cumulative abnormal return for the time window during the time window of By-Health equity incentive plan

\begin{tabular}{lllllllll}
\hline & CAR [-15,-1] & CAR [-5,-1] & CAR [--1,0] & CAR [0 3] & CAR[-15, 15] & CAR [-10, 10] & CAR [1, 10] & CAR [1, 15] \\
\hline Equity incentives & $7.94 \%$ & $4.50 \%$ & $-7.43 \%$ & $-5.26 \%$ & $7.15 \%$ & $8.58 \%$ & $7.96 \%$ & $6.64 \%$ \\
\hline
\end{tabular}

As can be seen from the above table, the response was not apparent when By-Health's announcement of the draft equity incentive was not apparent, and the excess cumulative yield CAR grew significantly over the previous half of the year as compared to the previous day, but was almost flat compared to the previous half-month market. At the same time, it was found that the accumulated excess yield had fallen sharply before the announcement date of the equity incentive draft, which led to the announcement of the draft, although the cumulative excess yield was increased by about $15 \%$, but it was only restored to normal levels. This indicates that the market's recognition of the stock ownership incentive scheme is not high.

\subsubsection{Institutional Investor Change Analysis}

In the first year of the company's equity incentive program, the performance of the company is prominent, the control ability of the company is stronger than that of the previous year, so many fund institutional investors are gaining the favor and institutional investors come to invest. From the table, it can be seen from 66 in 2012 to 126 in 2013, up 90.9\% on a year-on-year basis. But we can see at the same time that rational institutional investors in 2014 have left By-Health, and we have said in the previous paper that By-Health is far less than expected in 2014, leading to failures of rights exercise. The large-scale departure of institutional investors is also linked to their dislike to By-Health. Although institutional investors in 2015 were joining By-Health, the number of institutions rose from 87 to 195, but we couldn't ignore the fact that although institutional investors surged, the total number of shares was not high. If only the total number of institutional shares is roughly divided into each institutional investor, the average holding capacity of each institution is about 32.5 million shares, much less than the average holding capacity of 45.5 million units per institution in 2012.It is not easy to find out here that there are a large number of small investors in institutional investors in 2015, or that big institutional investors are simply investing in small-scale capital investment by By-Health, explaining that most institutional investors are rational investors, Their cautious investments in capital markets, on the other hand, illustrate that institutional investors are not very popular with By-Health, at least compared with the base year.

Table 8. Changes of Investors to By-Health

\begin{tabular}{|c|c|c|c|c|c|c|c|c|c|c|c|}
\hline \multirow{2}{*}{$\begin{array}{l}\text { Report } \\
\text { period }\end{array}$} & \multicolumn{5}{|c|}{ Total number of institutional holdings ( 10,000 shares $)$} & \multicolumn{5}{|c|}{ Total institutional shareholding ratio (\%) } & \multirow{2}{*}{$\begin{array}{c}\text { Number of } \\
\text { institutional } \\
\text { speculators } \\
\text { Total }\end{array}$} \\
\hline & Total & $\begin{array}{c}\text { General } \\
\text { legal } \\
\text { person }\end{array}$ & Fund & $\begin{array}{l}\text { Securities } \\
\text { company }\end{array}$ & Others & Total & $\begin{array}{c}\text { General } \\
\text { legal } \\
\text { person }\end{array}$ & Fund & $\begin{array}{l}\text { Securities } \\
\text { company }\end{array}$ & Others & \\
\hline $2012 / 12 / 31$ & 3004.78 & - & 3004.78 & - & - & 13.74 & - & 13.74 & - & - & 66 \\
\hline $2013 / 12 / 31$ & 7345.48 & - & 7345.48 & - & - & 22.39 & - & 22.39 & - & - & 126 \\
\hline $2014 / 12 / 31$ & 3987.45 & - & 1902.17 & 165.27 & 1920.02 & 2.89 & - & 2.89 & 0.25 & 4.99 & 87 \\
\hline $2015 / 12 / 31$ & 6340.73 & - & 5380.7 & 271.93 & 688.11 & 8.71 & - & 7.39 & 0.37 & 0.95 & 195 \\
\hline
\end{tabular}

3.4.3.3 Investment Return Rate Analysis

By-Health's continuous equity incentives will change investors' expectations about the company's future earnings and be reflected on the company's stock price. In this paper, we analyzed the investment return on investment from 2012 to 2015, taking into account the change of dividend and share price, and compared the return rate of Shenzhen A stock market. As shown in the figure below, we found that the market return rate of By-Health Company was much higher than that of stock market. The market was excellent, but a sudden drop in 2014 and a negative figure, which rose slightly in 2015. 


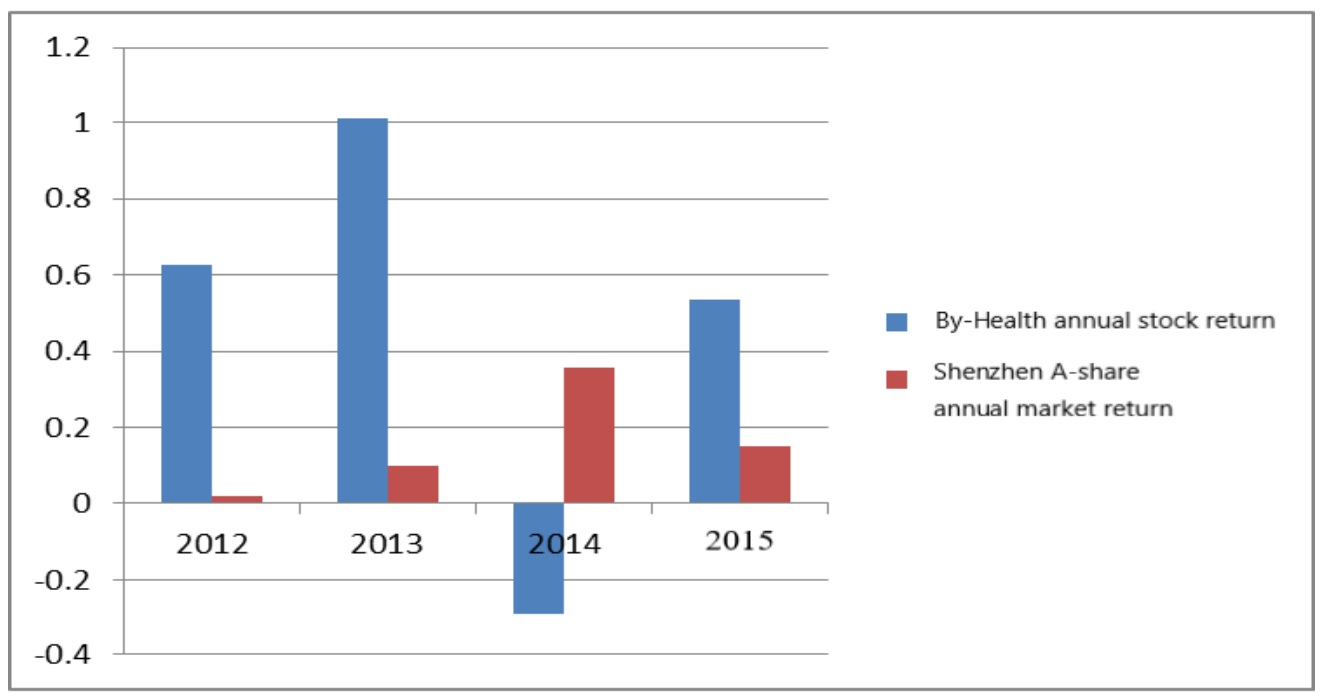

Figure 4. Comparison of annual return rate and the return rate of Shenzhen A-share

\section{Enlightenment of Case Analysis}

In the light of the specific measures and results of the equity incentive of By-Health Company, we believe that the following three points should be paid more attention when implementing the equity incentive scheme:

Range of incentives. For By-Health, the incentive targets of equity are mainly managers of middle-level managers, core technologies (business) and sub-(son) companies of the company, with a total of 135 people, but the highest bidder's income is only 80000 shares, and the share of equity is relatively small. In addition, By-Health's equity incentive target does not include senior managers such as deputy managers. For an enterprise, executives are the head of the enterprise and the implementer of the enterprise plan, so you can think that the incentive targets do not include executives like the vice president. The effect of equity incentives may be limited, as the success of equity incentives does not matter for such senior managers and does not affect their performance and pay, and naturally it is difficult to mobilize their enthusiasm, to achieve the goal of further improving the company's operating performance and promoting the company's comprehensive competitiveness. As the beneficiary of the equity incentive scheme of the Company, the incentive objects are likely to gain considerable capital gains in the short term, while the remaining gains of the Company are enjoyed in the long term, but the short-term earnings are more enticing. The nature of equity incentive can be further analyzed from the scope of incentive object. If the incentive range only benefits the directors, management and very few employees of the company, equity incentives are likely to benefit executives. Corporate governance as a whole is the result of the common role of governance structure and governance environment. The key positions of core technical personnel and sales department of the sales department are not stimulated, the incentive is difficult to produce effect, and the absence of incentive may result in the dissatisfaction of the employee who should be encouraged. Therefore, when implementing equity incentive measures, listed companies must focus on the scope of incentives. If the incentive targets do not include some executives, some of the executive's enthusiasm is not high, and the effect of equity incentive may be limited; Similarly, if only certain executives are rewarded and other employees are dissatisfied, it is also possible to result in an imperfect incentive effect or even a negative effect.

Rights exercise validity period setting. By the period of one year between the unlocking periods set by the equity incentive scheme of By-Health company, many times of unlocking can provide long-term incentive to the enthusiasm of the employees, and the long-term validity period can better measure the performance of the employees. The speculators should prevent the speculators from cheating on the performance of the performance appraisal for short-term performance appraisal. The long-term validity life is a key factor to measure the incentive of equity incentive. In a long period of time, management should face performance pressure, each issue is bound by the incentive conditions, and the ability of executives to manipulate the performance index during long-term incentive processes is significantly weakened. Firstly, performance indicators are likely to be manipulated in a short period of time, and if the deadline is long enough, a lot of performance indicators managed through profit management will be reversed, and may be manipulated very small. So the effectiveness of equity incentive is obviously higher than that of short-term equity incentive.

Whether the grant of stock option is appropriate. By-Health is proposed to grant a stock option of 3.233 million shares, only $19.6 \%$ of the total share capital of the company when the incentive plan is signed; From the whole situation of 
GEM, the proportion of equity incentive granted by most enterprises accounts for about $3 \%$ to about $5 \%$ of total share capital. Such a relatively small number of incentive schemes can make equity incentives less effective because of weak incentives, and the fact is that. Therefore, the listed company carries out the equity incentive scheme, the proportion of the equity option grant amount accounting for the total share capital is not too low, otherwise the incentive intensity is not big, the manager's enthusiasm is not high, the actual effect of the equity incentive can not reach the expectation.

\section{References}

Bertrand, M., \& Mullainathan, S. (2001). Are CEOs Re- warded for Luck? The Ones without Principals Are. Quarterly Journal of Economics, 116, 901-932. https://doi.org/10.1162/00335530152466269

Chen, Y., Liao, G. M., \& Wang, T. (2005). An Empirical Analysis of the Incentive Effect of Listed Companies in China. Management World, (02), 158-159.

Dechow, P., \& Sloan, R. (1991). Executive Incentives and the Horizon Problem. Journal of Accounting and Economics, 14, 51-89. https://doi.org/10.1016/0167-7187(91)90058-S

Healy, P. M. (1985). The Effect of Bonus Schemes on Accounting Decisions. Journal of Accounting and Economics, 7 , 85-107. https://doi.org/10.1016/0165-4101(85)90029-1

Huang, H., Zhang, M., \& Liu, L. (2014). "Repurchase + Dynamic Assessment"-restricted stock incentive contract model study-Discussions on the Kunming Pharmaceutical Equity Incentive Scheme. Accounting Study, (02), 27-33 $+94$.

Johnson, A. (1999). Should Options Reward Absolute or Relative Shareholder Returns? Compensation and Benefits Review, 31, 38-43. https://doi.org/10.1177/088636879903100106

Lan. B. H. (2002). Study on the Efficiency of Executive Stock Option System. Graduate School of Social Sciences, China.

Li, C. L., \&Ren, L. L. (2013). A Case Study on the Influence of Equity Incentive to the Stock Market-Yili vs. Shenzhenye A. Management Modernization, (01), 97-100.

Lv, C. J., Zheng, H. L., Yan, M. Z., \& Xu, J. J. (2009). Equity Incentive System Design of Listed Companies: Incentive or Welfare? Management World, (09), 133-147 + 188.

Pan, Y., \& Liu, G. S. (2009). Study on the Incentive Effect of Equity under the Dual-entrusted Governance Framework. Economic and Social Commission, (06), 73-76.

Wang, J. X. (2012). Reflections on Yili Group Equity Incentive Scheme. Financial and Accounting Researches, (18), 57-59.

Wang, Q. X., \& Chen, X. Y. (2009). Empirical Study on Economic Performance of Equity Incentive in Listed Companies. Friends of Accounting (Mid-Year), (11), 79-82.

Xia, Y. (2014). Managers' Power, Equity Incentive and R \& D Investment-Empirical Analysis Based on China's Listed Companies. R\&D Management, 26(04), 12-22.

Xue, Q. (2015). Analysis of operation mode of stock-financing platform in our country. Guangdong University of Finance and Economics.

Zhang, Y., \& Zheng, X. Q. (2008). Empirical Study on the Market Response of Equity Incentive and on Insider Trading. East China Economic Management, 22(12), 155-158.

Zhao, H. W. (2016). Equity incentives, corporate governance and corporate performance-empirical evidence based on our listed companies. Macroeconomic Research, (12), 151-159.

\section{Copyrights}

Copyright for this article is retained by the author(s), with first publication rights granted to the journal.

This is an open-access article distributed under the terms and conditions of the Creative Commons Attribution license which permits unrestricted use, distribution, and reproduction in any medium, provided the original work is properly cited. 